\title{
Review on Dynamic Simulation of Wind Diesel Isolated Microgrids
}

\author{
Rafael Sebastián (1)
}

check for

updates

Citation: Sebastián, R. Review on Dynamic Simulation of Wind Diesel Isolated Microgrids. Energies 2021, 14, 1812. https://doi.org/10.3390/ en14071812

Academic Editor: Antonino Laudani

Received: 17 February 2021

Accepted: 21 March 2021

Published: 24 March 2021

Publisher's Note: MDPI stays neutral with regard to jurisdictional claims in published maps and institutional affiliations.

Copyright: (C) 2021 by the author. Licensee MDPI, Basel, Switzerland. This article is an open access article distributed under the terms and conditions of the Creative Commons Attribution (CC BY) license (https:// creativecommons.org/licenses/by/ $4.0 /)$.
Department of Electrical, Electronic and Control Engineering (DIEEC), Universidad Nacional de Educación a Distancia (UNED), 28040 Madrid, Spain; rsebastian@ieec.uned.es; Tel.: +34-913987624

\begin{abstract}
Wind diesel isolated microgrids (WDIMs) combine wind turbine generators (WTGs) with diesel generators (DGs) to supply electricity to remote consumers. WDIMs are low-inertia isolated power systems where large system frequency and voltage variations occur. WDIM dynamic modeling allows short-term simulations to be performed and detailed electrical variable transients to be obtained so that the WDIM power quality and stability can be tested. This paper presents a literature review about WDIM dynamic simulation. The review classifies articles according to factors such as the different WDIM operation modes (diesel only, wind-diesel and wind only) simulated, the types of WTGs used in the WDIM (constant- and variable-speed types), or the use of different short-term energy storage technologies (batteries, ultracapacitors, flywheels) to improve the WDIM power quality, stability and reliability. Papers about the dynamic simulation of related isolated microgrids are also reviewed. Finally, as an example of WDIM dynamic simulation, a WDIM with one WTG, one DG, load and a discrete dump load (DL) is modeled and simulated. The WDIM response to variations of wind speed and load consumption is shown by graphs of the main electrical variables. The simulations show how the DL is used to improve the WDIM stability and reliability.
\end{abstract}

Keywords: diesel generator; wind turbine generator; isolated microgrid; power system simulation; power quality; power system stability

\section{Introduction}

Wind diesel isolated microgrids (WDIMs) are microgrids that combine wind turbine generators (WTGs) with diesel generators (DGs) to supply electricity to remote consumers. WDIMs are in many cases the retrofitting of an existing isolated diesel microgrid with WTGs when there is an available wind resource at the diesel microgrid location. By means of the WTG-supplied power, the DG-demanded power is reduced so that the fuel consumption and the $\mathrm{CO}_{2}$ emissions are also reduced. Figure 1 shows a WDIM scheme where the main components of a WDIM, namely the wind turbine generator (WTG), diesel generator (DG) and consumer load, can be seen. Only one DG and one WTG are shown for simplicity, but WDIMs can include several DGs and/or WTGs. The DG consists of a diesel engine (DE) driving the rotor of a synchronous machine (SM). The DE converts fuel energy into shaft mechanical energy by the combustion of the fuel in the DE cylinders. The DE speed is controlled by the DE speed governor which actuates on the fuel rate incoming into the DE cylinders to control the DE-produced mechanical power. The DE mechanical power is converted into electrical power by the SM, which also provides the sinusoidal grid voltage waveform of frequency $f$ and amplitude V. The SM output voltage amplitude $\mathrm{V}$ is controlled by an automatic voltage regulator by regulating the SM reactive power injected in the microgrid. The WTG consists of a wind turbine (WT) driving the rotor of an electrical generator. The WT converts the wind power into shaft mechanical power. The WT mechanical power is converted into electrical power by the WTG electrical generator. The WTG electrical generator can be connected directly to the grid or through a power converter. The dump load (DL) consists of a resistor bank connected to the grid through power switches or an electronic power converter. The DL behaves as a controlled active power consumer. The energy storage system (ESS) consists of short-term energy storage 
technology suitable for grid applications [1] (based on flywheels, batteries, ultracapacitors, etc.) connected to the grid through an electronic power converter. The ESS behaves as a controlled active power producer/consumer. The reactive power block supplies reactive power to the isolated grid. It can be a synchronous condenser, a static VAR compensator or integrated into the ESS electronic power converter.

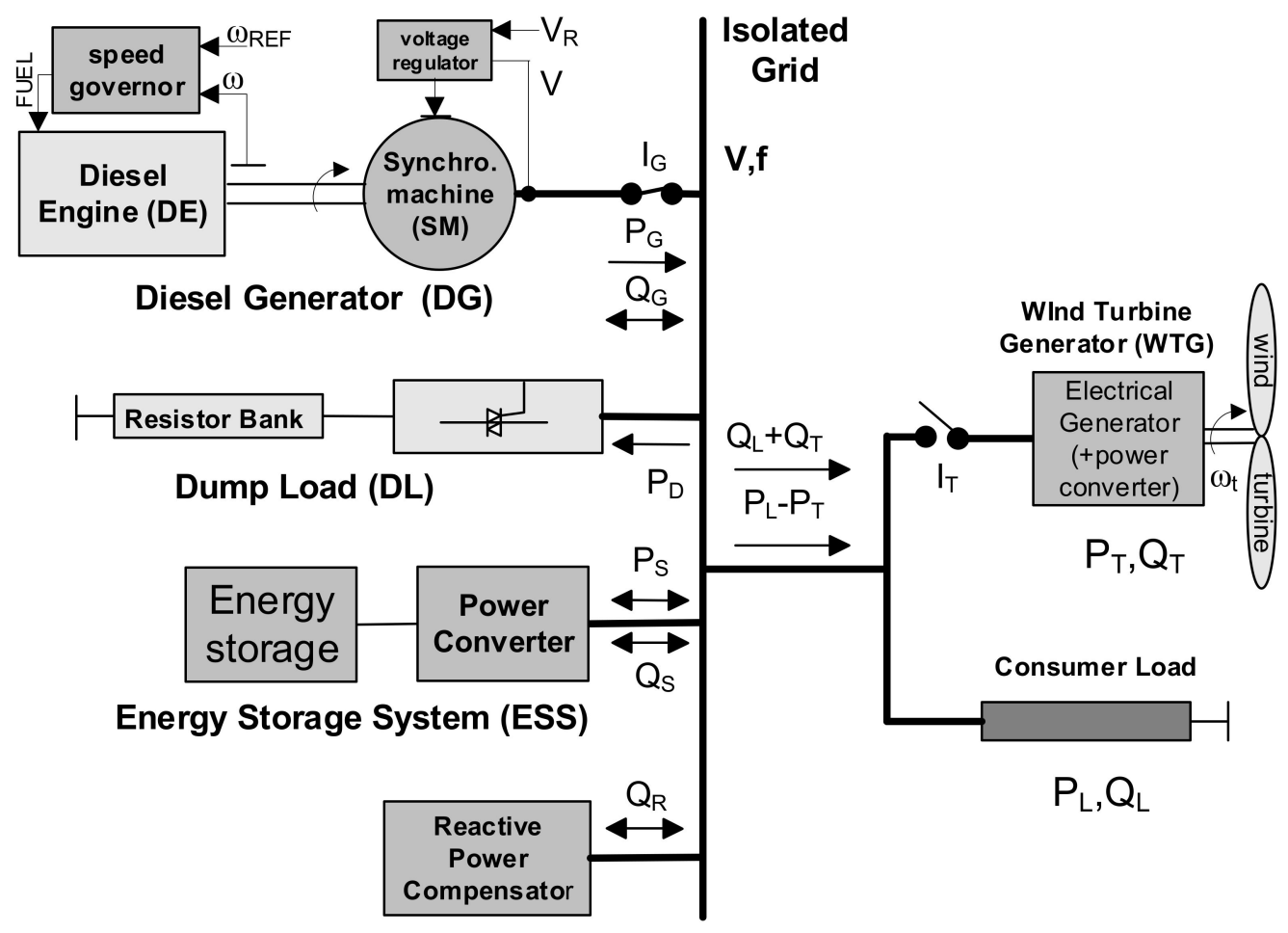

Figure 1. Wind diesel isolated microgrid scheme.

\section{WDIM Operation Modes}

All WDIMs have two modes of operation: diesel only (DO) and wind-diesel (WD) [2,3]. High-penetration WDIMs are capable of working with the DGs not running working mode known as Wind Only (WO)). The three modes of operation and the conditions to transition among them are shown in Figure 2.

In DO mode, the WDIM behaves as an isolated diesel power plant, and all the consumers' active and reactive power demands are supplied by the diesel generators (WTGs are disconnected in DO mode, $\mathrm{I}_{\mathrm{T}}=$ off in Figure 1). The regulation of the frequency is performed by the DE speed governors. The regulation of the voltage is performed by the SM voltage regulators.

The WTGs can supply active power with wind speeds above the WTG cut-in speed and below the cut-off speed. As Figure 2 shows, when the wind speed is inside the previous limits during a predefined $\mathrm{T}_{\mathrm{WD}}$ time interval to confirm enough wind resource, the WDIM control orders the connection of the WTGs, performing a DO-to-WD mode transition. Conversely, the WDIM control orders the disconnection of the WTGs when the wind speed is outside of the cut-in/out limits (WD-to-DO transition).

In WD mode, both WTGs and DGs supply active power. The regulation of the WDIM voltage and frequency is performed as in DO mode. The DE governor can only control frequency if the DE produces positive power, and a DL is required to guarantee this constraint. The WTG-produced active power $P_{T}$ can exceed the power consumed by the load $P_{L}\left(P_{T}>P_{L}\right)$, and if there is no means in the WTG to reduce its power (e.g., by varying the blade pitch), the WDIM control must order the DL to dump the necessary active power $P_{D}$ to keep the DG power positive $P_{G}$ and thus to avoid DG reverse power. Therefore, this DL use increases the WDIM reliability. The ESS can also load the system in WD mode to 
keep the DG power positive when $P_{T}>P_{L}$ [4], with the advantage that the WTG excess power stored in the ESS can later be mostly recovered. ESSs can provide fast reserve power [5] that can be used to reduce the spinning reserve needs in both DO and WD modes. Additionally, for DO/WD modes, ESSs can improve the efficiency of DGs by increasing DG loading (low-loaded DGs have low performance).

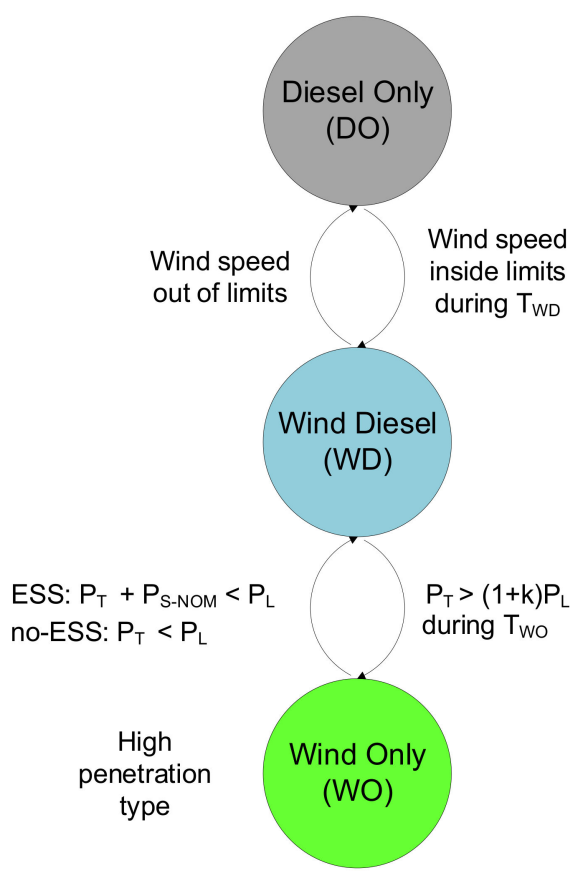

Figure 2. Wind diesel isolated microgrid (WDIM) operation modes and transitions between modes.

As Figure 2 shows, if the WTG-produced power exceeds the load consumption $\left(P_{T}>P_{L}\right)$ (increased by a security factor $\mathrm{k}$ ) during a predefined $\mathrm{T}_{\mathrm{WO}}$ time interval, to confirm the WTG active power excess, and the WDIM is a high-penetration one, the WDIM control orders the DGs to stop, performing a WD-to-WO mode transition.

In WO mode, the active power is supplied only by the WTGs. In this mode, as the DGs are not running, no fuel is consumed and the WDIM voltage and frequency control must rely on auxiliary components. In a no-storage WDIM, the condition for WO mode is that the WTG-produced power $P_{T}$ must exceed the load-consumed power $P_{L}$ plus the system losses constantly. The active power generated by the WTGs ranges from partly controlled to totally uncontrolled depending on the WTG type. As the consumer load is uncontrolled, the DL is ordered to consume the WTG power excess to match generation with consumption to regulate WDIM frequency. When the WO mode condition is not met $\left(P_{T}<P_{L}\right)$, there will be an active power deficit that will be detected by a system frequency falling, and the WDIM must transition from WO to WD, as Figure 2 shows. The WDIM control will order the DG to start and connect it to the isolated grid. Once the DG is connected, the WDIM will be in WD mode, and the DG will supply power to balance the WDIM active power to restore the frequency to its rated value [6]. If an ESS is included in the WDIM, the WTG power excess can be stored in the ESS or dumped in the DL, or both actions can be taken in a coordinated way. In addition, when the current load is above the WTG power, the ESS can supply power $P_{S}$ up to its rated power $P_{S-N O M}$ (temporally until the ESS is discharged). In a WDIM with an ESS, the condition for WO mode is that the WTG-produced power $P_{T}$ plus $P_{S-N O M}$ (ESS rated power) must exceed the load consumption $P_{L}$ (neglecting the losses). As Figure 2 shows, if the previous condition $P_{T}+P_{S-N O M}>P_{L}$ is not satisfied, the WDIM control will start and connect a DG [7], changing from WO to WD mode.

If an SM is running and connected to the grid in WO mode, the SM will generate the microgrid voltage, and the voltage regulation will be performed by the SM voltage 
regulator as in DO and WD modes. The WDIM active power active unbalances will be translated into frequency variations [8]. If the voltage waveform is generated by a voltage source inverter (VSI) which connects either a WTG or an ESS to the grid, and the VSI works with constant frequency, the WDIM active power unbalances will be translated into voltage variations [9].

\section{WDIM Dynamic Simulation Review}

WDIM simulations can be of two types: logistic and dynamic. The logistic simulations allow long-term WDIM simulations in terms of energy balance and can be used to test a particular WDIM architecture and for the sizing of the different components of the WDIM. Examples of logistic simulation software are Hybrid2 [10] and Homer [11]. The input data to these programs are the WDIM architecture, the estimated load consumption and the WDIM location wind speed data. These logistic simulation tools produce as output important results such as the fraction of energy that the WTGs supply, the fuel savings achieved, the total DG run time, the number of DG starts and the cost of energy. There are also articles that deal with the generator sizing of a specific WDIM, such as [12], with the aim in this case of optimizing the dynamic power-sharing between the DG and WTG.

WDIM dynamic simulations allow short-term simulations in order to obtain detailed electrical variables waveforms, such as system voltage and frequency and active and reactive power in the different elements, so that the WDIM power quality and stability can be tested. For WDIM dynamic simulations, the most used software are PSCAD [13], which is focused on power system modeling and simulation, and Matlab-Simulink along with the Simscape Electrical [14] library (Simscape Electrical includes power system modeling). The RPM-SIM Simulator [15] has also been used in WDIM dynamic simulation.

In the dynamic simulation of big power systems, the system frequency is assumed to be constant, and this assumption allows the use of low-order dynamic models for the electrical machines in big power system modeling. WDIMs are low-inertia isolated power systems, and therefore, the WDIM frequency can suffer strong variations [7]; thus, according to [16], low-order electrical machine models should not be used in WDIM modeling. Therefore, to obtain precise voltage waveforms in the dynamic simulations, the WDIM modeling must use high-order-type electrical models for the electrical machines included in the WDIM (these high-order models are available on both Simscape Electrical and PSCAD).

This section classifies articles according to several factors, which are dealt with in the following subsections.

\subsection{WTGs Included in WDIMs}

The three types of generator systems most used in WTGs [17] are shown in Figure 3. The low-cost one is the WTG that equips a squirrel-cage induction generator (SCIG), which has the stator directly connected to the grid (Figure 3a). This combination of a WT driving a SCIG is called a constant-speed WTG, because for generator operation the SCIG speed range is very narrow, typically between 1.01 and 1.02 the synchronous speed [18]. This WT-SCIG set does not allow the variation of its speed to optimize the wind energy capture [17], but it has remarkable features for the remote locations of WDIMs, such as robust construction and simple maintenance [19]. Since the SCIG consumes reactive power, a capacitor bank is added for reactive power compensation. Additionally, the SCIG-produced torque is proportional to the SCIG slip in the WT-SCIG working speed range [20], and due to the SCIG being directly connected to the isolated grid, the WTG inertia increases the system inertia. These two WT-SCIG features provide significant frequency support, moderating system frequency deviations [21]. This WT-SCIG type is used in the WDIM simulations of [22-29]. 


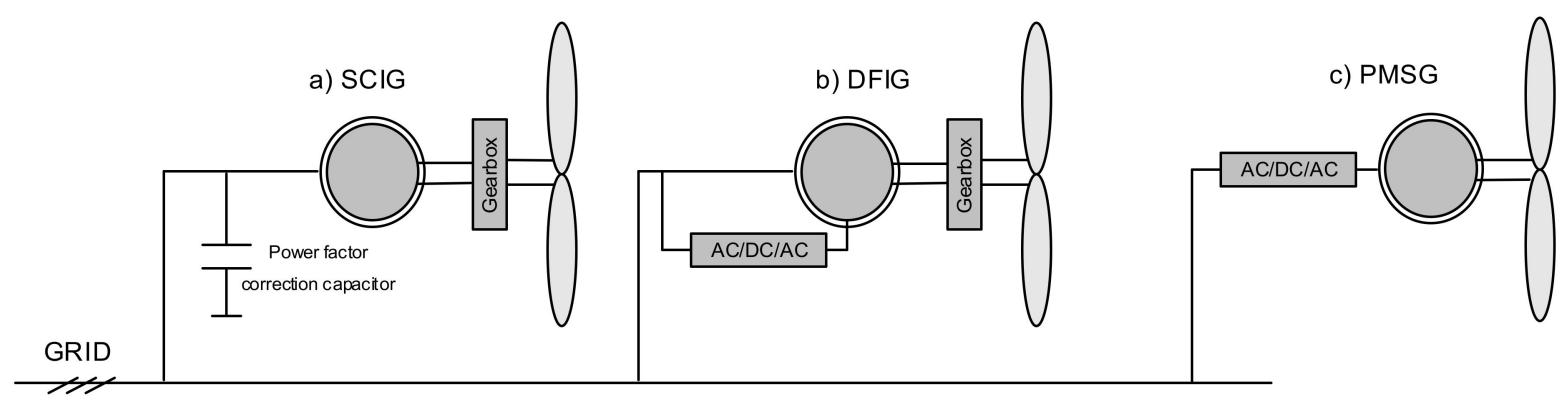

Figure 3. SCIG, DFIG and PMSG Wind Turbine Generators types.

Variable-speed WTGs allow the optimization of the wind energy capture and are mainly of two types [17]: the double-feed induction generator (DFIG) (Figure 3b) type and the permanent magnet synchronous generator (PMSG) type (Figure 3c).

The DFIG type has its stator directly connected to the grid, and its rotor is connected through a slip ring to an AC-DC-AC converter to the grid. This rotor converter controls the rotor frequency and therefore the rotor speed that can be varied in a range of $\pm 30 \%$ around the synchronous speed [18]. The rotor converter rated power is only $25-30 \%$ of the DFIG rated power, which is an advantage when compared with other variable-speed WTG types. The slip rings need periodic maintenance, which is a drawback for the remote sites of WDIMs. This WT-DFIG type is used in the WDIM simulations of [30-32]. The SCIG and DFIG WTG types need a gearbox to adjust the low WT speed (10-15 rpm) to the high IG rotor speed (for example, $750 \mathrm{rpm}$ for a four-pole-pair IG and $50 \mathrm{~Hz}$ grid frequency). The gearbox has friction losses that decrease the WTG efficiency, and it needs periodic maintenance.

The third WTG type considered consists of a WT that directly drives (no gearbox) a PMSG connected to the grid through an AC-DC-AC double converter. The gearbox disadvantages are avoided, but as the SG rotates at the low WT speed, the SG must produce high torque to deliver the rated power; therefore, a larger size of the generator is needed [17]. The double converter makes the WT-SG rotor speed independent from the grid frequency and allows a rotor speed range from 0 to rated one. The double converter rated power has to be equal to the PMSG rated power as all the WTG-produced power has to pass through the converter, so the converter losses are greater than in the WT-DFIG type. In [33-35], the simulated WDIMs include a WT-PMSG type. In the WDIM of [36], the WT drives an electrically excited SG instead of a PMSG. Another interesting feature of the WT-PMSG type is that the DC-AC grid power converter can generate the isolated grid $\mathrm{AC}$ voltage and regulate the $\mathrm{AC}$ voltage amplitude and frequency, making the WO mode architecture simpler.

Variable-speed operation in WTs has additional advantages such as the reduction in torque peaks in the gearbox and shafts in the DFIG-WTG type and the possibility of using the kinetic energy of the blades to absorb wind power fluctuations, which is an interesting feature in WDIMs. Variable-speed WTGs can also support system frequency if this feature is included in their controllers [21]. Additionally, the AC-DC-AC converter of the variablespeed WTGs allows a battery to be connected to the DC side of the converter [37] so that the battery ESS (BESS) is embedded into the WTG. This embedded BESS can be used to improve the frequency support previously mentioned or to smooth the WTG power output.

\subsection{Use of Energy Storage in WDIMs}

The aim of the ESSs in a WDIM can be logistic, in order to reduce the start-stop cycles of DGs [38] and/or to improve the WDIM stability and power quality [8]. A significant reduction of the cycling of DGs can be achieved with an ESS with a rated power around the average WDIM load and with a storage time of several minutes, having an acceptable reduction with just 1 min of storage time [38]. In [39], the logistic modeling SW Hybrid2 [10] is used to determine an optimum storage time of 10-15 min for the average WDIM load 
to reduce the DG cycling. The rated power of WDIMs goes from tens of $\mathrm{kW}$ to $\mathrm{MW}$, so this is also the power range of ESSs for WDIMs. In this section, short-term ESSs based on batteries (BESSs), supercapacitors (CESSs) and flywheels (FESSs) are briefly considered as these types comply with the ESS rated power and storage time requirements previously mentioned. Additionally, BESSs, CESSs and FESSs are compared in terms of cycle life, as any ESS in WDIMs must withstand a high number of charging-discharging cycles with variable depth of discharge as the ESS must continuously smooth the wind power, and wind power is of random nature. The structures of the three ESS types considered are presented in Figure 4.

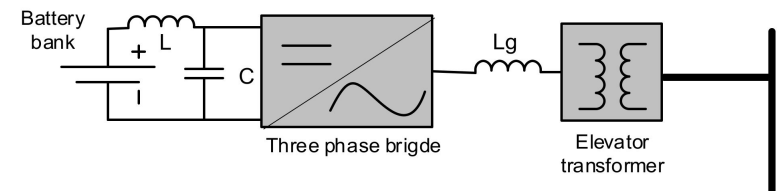

a) Battery based Energy Storage System (BESS)

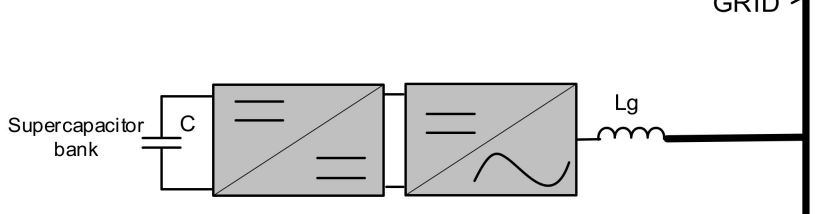

b) Supercapacitor based Energy Storage System (CESS)

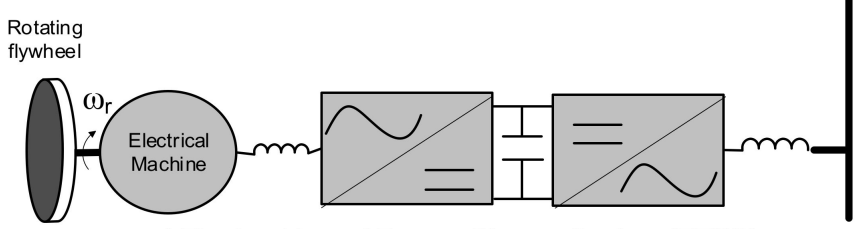

c) Flywheel based Energy Storage System (FESS)

Figure 4. Structures of energy storage systems (ESSs) based on (a) batteries (BESSs), (b) supercapacitors (CESSs) and (c) flywheels (FESSs).

Battery energy storage systems (BESSs) (Figure 4a) consist of a battery bank, a threephase bidirectional power converter to convert the DC battery voltage into the AC grid voltage and additional filters to smooth the battery current and to limit the grid harmonic injection. The power converter works as an inverter/rectifier to discharge/charge the battery to/from the grid. The modeling of one of these converters working in current-controlled mode can be seen in [40]. In Figure $4 \mathrm{a}$, an elevator transformer matches the battery voltage with the AC grid voltage. This solution is feasible as batteries change voltage little when they discharge, but other solutions instead use a DC-DC buck-boost converter to elevate the battery voltage up to the needed DC input voltage in the inverter [41]. Reference [42] shows different dynamic BESS models. The battery types that have been used in WDIMs are $\mathrm{Pb}-$ acid, $\mathrm{Ni}-\mathrm{Cd}, \mathrm{Ni}-\mathrm{MH}$ and Li-ion [43]. Reference [44] presents an electrical model for batteries consisting of a variable voltage source in series with a constant resistor. The DC variable voltage source follows the volts-state of charge (SOC) battery discharge curve. Reference [45] improves a previous model by proposing different resistances for charging and discharging, these resistances being a function of SOC. Battery SOC calculation is not simple. Reference [46] proposes battery SOC estimation, integration of the battery current and tracking of battery voltage variations. In [47], the Volterra models are applied to calculate battery SOC. The relationship between the battery number of cycles and the depth of discharge is that of an exponential decrease [48]. The maximum number of cycles for a battery depends on the battery type. WDIM simulations including a BESS in their architecture can be found in $[4,19,34,40,49]$.

Supercapacitor energy storage systems (CESSs) (Figure 4b) consist of a supercapacitor bank, a bidirectional DC-DC converter, a DC-AC three-phase bidirectional power converter 
and a grid connection filter. Unlike batteries, supercapacitors present significant voltage drop as they discharge, so a DC-DC converter is needed in this case [50] to adapt the supercapacitor DC voltage to the DC voltage needed at the input of the DC-AC grid converter. The simplest electrical model for supercapacitors consists of a series of a capacitor and a resistance along with a parallel resistance which takes account of the autodischarge process. Compared to batteries, supercapacitors have higher specific power $(\mathrm{W} / \mathrm{kg})$ and much higher cycle life and allow simpler measurement of the state of charge (by means of the supercapacitor voltage), but they have lower specific energy (Wh/ $\mathrm{kg}$ ) and much higher cost. Reference [51] includes a CESS in its WDIM simulations. By combining the high power density of supercapacitors with the high energy density of batteries, an optimum ESS is achieved [52]. In [35], the WDIM includes a mixed CESS-BESS.

FESSs (Figure 4c) consist of a rotating flywheel, an electrical machine that drives the flywheel and a double AC-DC-AC power converter to connect the electrical machine to the AC grid. Filters are needed to connect the double converter to the grid and to the electrical machine. A capacitor bank is connected to the DC side of the double converter. The energy is stored in the kinetic energy of the flywheel, and the electrical machine acting as a generator/motor converts the kinetic energy into electrical energy and vice versa. The bidirectional electrical machine side converter transforms the DC capacitor bank voltage into AC voltages for the electrical machine. The bidirectional grid side converter transforms the AC grid voltages into the DC voltage of the capacitor bank. The machine converter controls the electrical machine torque in order to maintain a constant DC voltage in the DC-link, so the control of the grid converter works in the same way as a battery converter. Compared to batteries, flywheels have higher cycle life and higher specific power $(\mathrm{W} / \mathrm{kg})$ and allow simpler measurement of the state of charge (only flywheel spinning speed is needed), but they have lower specific energy ( $\mathrm{Wh} / \mathrm{kg}$ ) and much higher cost.

Reference [53] deals with the modeling of the FESS double power converter. WDIM simulations which include a FESS can be found in [24,25,53,54].

Another type of short-term ESS that has been used in WDIM simulations is superconducting magnetic energy storage (SMES). Reference [55] uses SMES in the presented WDIM. A review on SMES and its potential applications in power systems can be seen in [56].

\subsection{Modes of Operation}

The literature about WDIM operation mode simulations deals with WDIMs of different architectures. The following papers present WD mode simulations in no-storage WDIMs. Reference [22] deals with a WDIM with one DG and one WTG and shows several simulations considering pitch or stall regulation WTs and WT-SCIG types or WTs driving SGs directly connected to the grid. In [23], the responses of a two-DG-three-WTG WDIM to sudden WTG disconnection and load demand variations are simulated. In the WDIM of [26], modifications to the DE speed governors are proposed to share active power among DGs in order to reduce the total fuel consumption. Reference [57] presents simulations of a WDIM whose fixed-pitch WT drives a dynamic slip-controlled wound rotor induction generator [58]. Reference [57] shows that by varying the rotor WRIG resistance as a function of the grid frequency by means of a variable external resistor, this WT-WRIG provides frequency support to the minigrid. ESSs have also be considered in WD mode simulations. Reference [24] simulates a WDIM with one WTG, one DG, a DL and a FESS based on hydrostatic transmission. In [25], a WDIM includes a high-speed flywheel driven by a switched reluctance electrical machine, and simulations with the WDIM response to WTG power and load increases are presented. Reference [59] models a WDIM with WT-SCIG, DG, BESS, load and power lines connecting all the elements, and it simulates the WDIM in response to a wind gust disturbance.

Several papers deal with simulations in WO mode. In the following papers, an SM provides the isolated grid AC voltage. Reference [29] models an isolated wind power system that consists of a WT-SCIG, SM, load and BESS. The simulation in [29] shows how 
the BESS is used to regulate frequency by consuming/supplying the WTG active power excess/deficit. Reference [54] deals with a similar architecture, except that the BESS is substituted by a low-speed flywheel driven by an induction electrical machine, and shows how the FESS is used to regulate the isolated system frequency. No-storage WDIMs have also been simulated in WO mode, such as in [6], which shows WDIM frequency regulation by using a DL which consumes the WTG power excess. An architecture similar to that of [6] is presented in [60], but [60] uses a different DL control for frequency regulation. In [61], the regulation of frequency is performed by a BESS and a DL that are coordinated to share the WTG power excess.

In other WO simulations, the grid converter of a WT-PMSG type generates the AC isolated grid voltage, and the frequency regulation is performed by regulating the DC link voltage of the WT-PMSG double power converter. Examples of this case are [34], where a DL and BESS combination regulates the DC link voltage; [35], where a BESS-CESS combination is used for the DC regulation; and [36], only a DL is used to balance the WTG active power generation excess.

The transitions between the different WDIM modes of operation have also been simulated in the literature. Reference [27] simulates a DO-to-WD mode transition by connecting a WT-SCIG to a DG isolated grid. Reference [62] shows a much smoother DO-to-WD transition than [27] as the WT-SCIG is equipped with a soft starter. In $[7,49,63]$, the simulated high-penetration WDIM has a DG with a friction clutch. By means of the clutch, the DE can be locked/disengaged to/from the SM. This clutch-type DG is shown in Figure 5. When the clutch is locked, the WDIM mode is DO-WD; when the clutch is disengaged, the WDIM mode is WO and the SM provides the AC grid voltage. The WO-to-WD transition in the clutch-type DG is faster than in the standard no-clutch DG [64] shown in Figure 1.

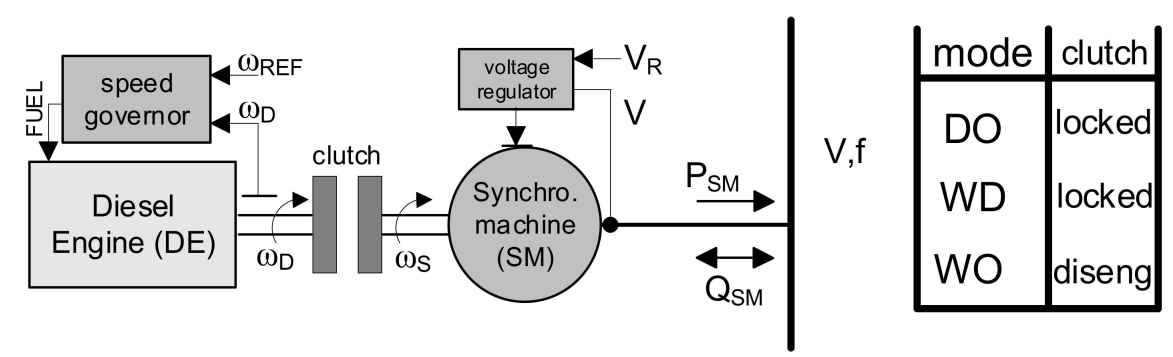

Figure 5. Clutch-type diesel generator (DG).

In the clutch-type DG, the clutch is ordered to engage when the DE and SM have quite similar speeds $\left(\omega_{D} \approx \omega_{S}\right.$ in Figure 5$)$ [7]. The no-clutch DG type shown in Figure 1 needs extra time to perform the synchronization of the SM voltage with the grid voltage before connecting the DG circuit breaker $\mathrm{I}_{\mathrm{G}}$ of Figure 1. The WO-to-WD transition simulation in [49] is done by locking the DE to the SM so that the DE produces in WD mode the power supplied previously in WO by the BESS. The WD-to-WO transition simulation of [63] is done by disengaging the DE from the SM when the WTG power generation exceeds the load consumption. Reference [7] simulates the mandatory WO-to-WD transition when power generation is below the power consumption. During this WO-to-WD transition case simulated in [7], there is a frequency falling due to the active power deficit until the clutch is locked. After the locking of the clutch, the DE supplies power and the active power equilibrium can be restored.

\subsection{Power Quality and Stability Issues}

As previously mentioned, WDIMs are low-inertia isolated power systems, where it is quite difficult to balance power generation with load consumption due to the uncontrolled power generated by the WTGs and consumed by the loads. These unbalances provoke significant system voltage and frequency deviations. Several papers deal with power 
quality and system stability studies in no-storage WDIMs: [27] studies how the variations of WTG power and load influence WDIM power quality, [65] shows the stabilization of the WDIM voltage by using the combination of a static reactive compensator and the SM voltage regulator, and [26] proposes modifications in the SM voltage regulators to reduce WDIM voltage variations. In [66], the DE speed governor is supported in the frequency regulation by controlling distributed heating loads. In [67], the control of the WTG couples the kinetic energy stored in a WT-DFIG with the rate of change of frequency to emulate inertia, increasing the total inertia of the WDIM and improving the frequency transients.

When a short-term ESS is included in a WDIM, it provides several benefits such as frequency and voltage stabilization and improved stability and reliability [8]. These benefits are more effective in WDIMs than in big power systems which have larger inertia. Reference [51] shows the stabilization of the WDIM frequency by using a capacitive ESS. Reference [68] uses a BESS with a redox flow battery type for frequency stabilization of a WDIM. In [40], the WDIM includes a Ni-MH BESS, and the study compares by simulation the responses for the BESS and no-BESS cases, showing much better transients in voltage and frequency in the BESS case. Similarly, [59] shows by comparing the BESS and no-BESS cases that the DG active and reactive power transients are greatly improved in the BESS case, as the BESS tracks and compensates for the WTG power changes. Reference [69] deals with a WDIM with DL and FESS and shows that the only-FESS case responses present better power quality than the only-DL case when they are used in WD mode to control an active power excess scenario. In [19], the simulated WDIM includes a BESS which performs a peak shaving strategy in order to avoid a DG overload scenario, improving the WDIM reliability. In [4], the WDIM control uses a BESS to increase the power consumption to avoid DG reverse power, so that the DE speed governor can continue controlling system frequency by regulating the DE fuel injection and the WDIM reliability is augmented. Reference [62] also shows how WDIM reliability is increased by ordering a generic ESS to load/supply when needed.

\subsection{Related AC Microgrids}

WDIMs are remote microgrids [70,71] that operate in an autonomous mode [72], so WDIMs can be related to other isolated microgrid studies. Reference [73] shows a BESS included in an isolated microgrid that provides frequency support and uninterrupted power supply of critical loads; this study is applicable to the ESS in a WDIM in the case of the generators being out of order. Reference [74] deals with a ship with a DG power plant that includes a BESS; the BESS smooths the ship power variation, and this study is applicable to a WDIM working in DO mode. In [75], new DG controllers are proposed to enable the operation of a DG in a microgrid that includes inverter-based sources avoiding circulating reactive power and frequency oscillations caused by standard DG controllers, so this study is applicable to the DGs included in WDIMs. Reference [76] presents graphs of the active and reactive power sharing between a DG and an inverter-based generator in a microgrid when frequency/voltage droop control is used. This study is applicable to a WDIM as ESSs and WT-PMSGs are always connected with an inverter to the grid.

In [77], a BESS is used to counteract the voltage variations caused by renewable power source power fluctuations; [78] presents a standalone microgrid with a BESS-CESS combination and with a fuzzy logic control system to stabilize frequency and voltage; in [79], a load shedding optimal control is carried out to reduce the fuel consumption during the operation time of a DG included in a microgrid with renewable power generation. The utilization of fuel cells to provide controllable active power has also be considered in WDIM and microgrid simulations. In such cases, the microgrid usually includes a water electrolyzer that consumes renewable power excess to produce hydrogen for the fuel cell. Reference [80] models and simulates a WDIM consisting of a DG, four pitch-controlled WTGs, load, a flywheel as short-term ESS and a fuel cell electrolyzer as a long-term ESS, and both ESSs are used to support the WDIM frequency regulation. Reference [81] simulates several cases of a microgrid that includes three WTGs, one DG, a photovoltaic system, two 
fuel cells and flywheel and battery ESSs. The isolated microgrid in [82] includes wind and photovoltaic generators and fuel cells but does not include a DG. Reference [82] combines a BESS and a CESS to control the frequency of a microgrid. Reference [83] shows an optimal sizing of a BESS used for frequency support in a microgrid with a DG, microturbine, fuel cell and photovoltaic generation.

DLs are also used to balance active power in isolated hydropower systems with no power regulation in the hydro turbine generator (HTG), and thus the DL is used to regulate system frequency [84]. This DL use is the same as that in WO mode in no-ESS WDIMs [6]. Additionally, WO mode simulations are also presented in the wind hydro isolated microgrid of [85], where a simulation of the transition from WO mode to windhydro mode (the mode where both the HTG and WTG are supplying) is also shown.

DGs and WTGs are also combined with other renewable power generators, such as in the power plant of El Hierro Island in Spain, which combines wind, hydro and diesel power sources. The diesel-off mode of this wind-hydro-diesel isolated grid has been simulated in several studies. Reference [86] shows how a rotating no-flow Pelton turbine can supply power in less than $10 \mathrm{~s}$ when the WTG-produced power is not enough to cover the load demand. In [87], the regulation of the system frequency in WO mode is performed by using the fixed- and variable-speed pumps which belong to the hydropower pumped-storage to balance active power. Reference [88] shows and compares different control schemes for frequency regulation in WO mode in the El Hierro isolated power system.

A broader study about different configurations and control of microgrids can be seen in [89].

\section{WDIM Dynamic Modeling and Simulation Example}

By using the Matlab-Simulink software, this section models a no-storage WDIM which comprises one $300 \mathrm{kVA}$ DG, one $275 \mathrm{~kW}$ fixed-pitch constant-speed WTG, consumer load and a $446 \mathrm{~kW}$ discrete DL. After the modeling, the WDIM is simulated, and the system response to wind speed and load variations is shown. The Simulink-SimPowerSystem schematic of the simulated WDIM is presented in Figure 6, and the dynamic modeling of the different components of the WDIM is presented next.

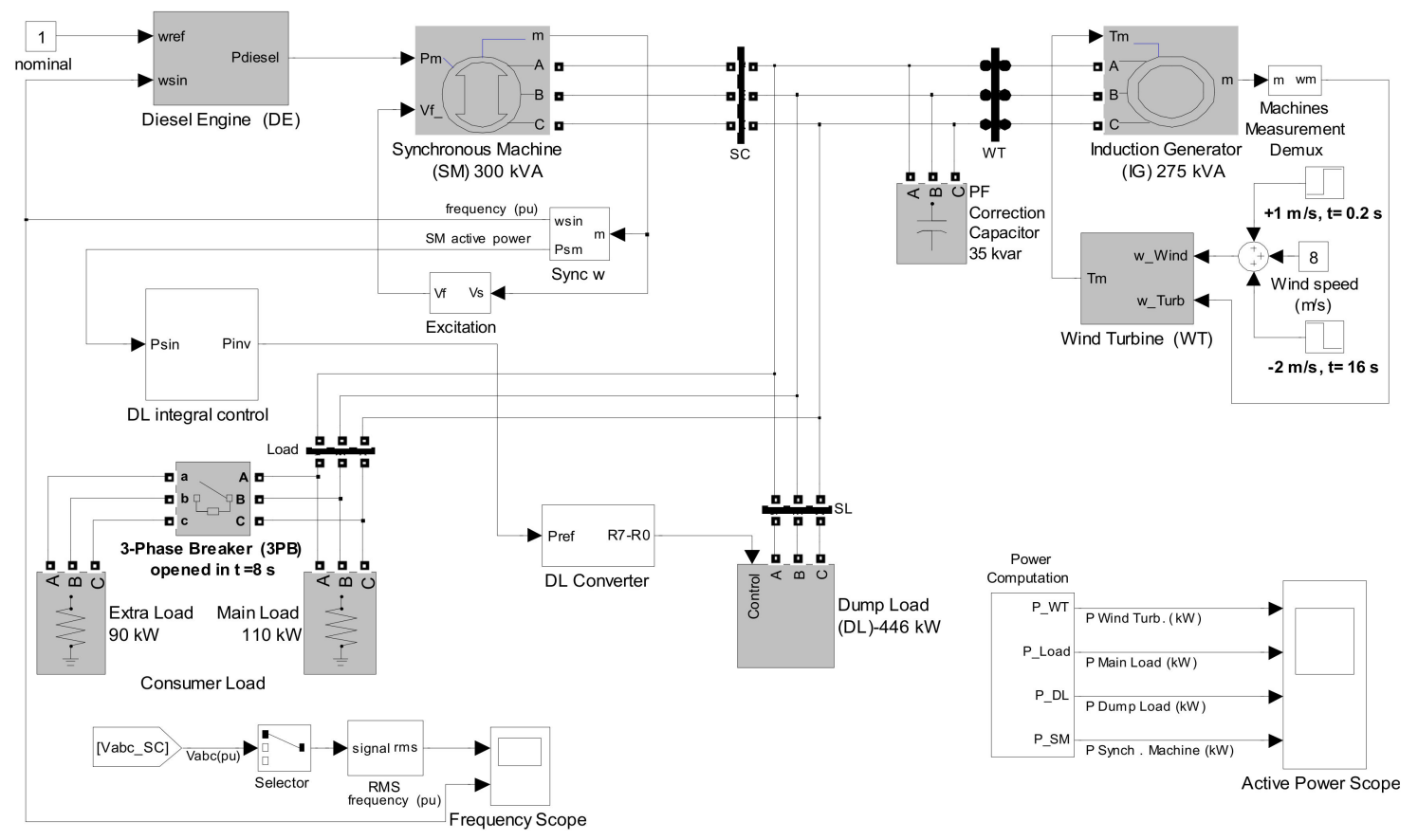

Figure 6. WDIM Simulink schematics. 


\subsection{Modeling of the WDIM Components}

The DG is built with the blocks of Figure 6: diesel engine, 300 kVA SM and voltage regulator. The sixth-order model of the SM and the IEEE type 1 voltage regulator model are available in the Simscape Electrical library [14]. The diesel engine block includes the models of the DE and its speed governor based on [90]. The DE model consists of a gain and a delay, and the speed governor consists of a speed regulator and actuator modeled as a second-order system. The speed regulator is a Proportional-Integral-Derivative (PID) type, and the PID integral part makes the WDIM frequency be the rated one in steady state.

The constant-speed WTG is represented in Figure 6 by the $275 \mathrm{~kW}$ induction generator block and the WT block that models the fixed pitch WT. The fourth-order model of the IG is available in the Simscape Electrical library [14]. The WT block is based on the wind turbine power curves [28] and uses a look-up table to calculate the produced mechanical WT shaft power as a function of the wind speed and the WT speed. The WT used has a fixed pitch, so there is no possibility of regulating its produced power, which mainly varies with the cube of the wind speed; therefore, the WT-SCIG generating power is uncontrolled. A $35 \mathrm{kVA}$ capacitor bank for reactive power support of the SCIG is included.

The $446 \mathrm{~kW}$ DL consists of eight three-phase resistors $\left(\mathrm{R}_{0}-\mathrm{R}_{7}\right)$, each one in series with an electronic switch $\left(\mathrm{S}_{0}-\mathrm{S}_{7}\right)$. By closing/opening the switch $\mathrm{S}_{\mathrm{J}}$, the corresponding three-phase resistor $R_{J}$ is connected/disconnected to/from the isolated grid, so the DL active power consumption can be controlled. The rated powers of resistors $R_{0}-R_{7}$ follow a binary progression and have the values $\mathrm{P}_{0}, 2 \cdot \mathrm{P}_{0}, 2^{2} \cdot \mathrm{P}_{0}, \ldots, 2^{7} \cdot \mathrm{P}_{0}$. The DL-consumed power ranges from 0 (all the switches OFF) to $255 \cdot \mathrm{P}_{0}$ (all the switches $\mathrm{ON}$ ), and the DL variation is discrete in steps of $\mathrm{P}_{0} \mathrm{~kW}$. For the present application $\mathrm{P}_{0}=1.75 \mathrm{~kW}$, and so $\mathrm{P}_{\mathrm{D}-\mathrm{NOM}}=446 \mathrm{~kW}$. The DL model is based on [28]. The DL is used in these simulations to avoid DG reverse power as explained in Section 2. For this aim, an integral action controls the DL-consumed power in such a way that the DG-produced power never goes below $12 \mathrm{~kW}$ in steady state. When the $P_{T}>P_{L}$ condition happens, the DL is ordered to consume power $P_{D}$ to allow the DG final power $P_{G}$ to be within a 12-18 kW minimum power interval (4-6\% DG rated power) so that the set DE + speed governor can control WDIM frequency.

\subsection{WDIM Simulation Graphics}

The simulation graphics show the main WDIM electrical variables: the frequency per unit (fpu) in Figure 7, the RMS voltage per unit in Figure 8 and the active powers of the DG, WTG, DL and consumer load in Figure 9. Figure 9 shows the active powers produced and consumed with positive and negative values, respectively, so the consumer load and DL plots are always below the $0 \mathrm{~kW}$ line. At the beginning of the simulation, the WDIM is in steady state, the DG and WTG produce 108 and $92 \mathrm{~kW}$ (for a wind speed of $8 \mathrm{~m} / \mathrm{s}$ ), respectively and the load and DL consume 200 and $0 \mathrm{~kW}$, respectively.

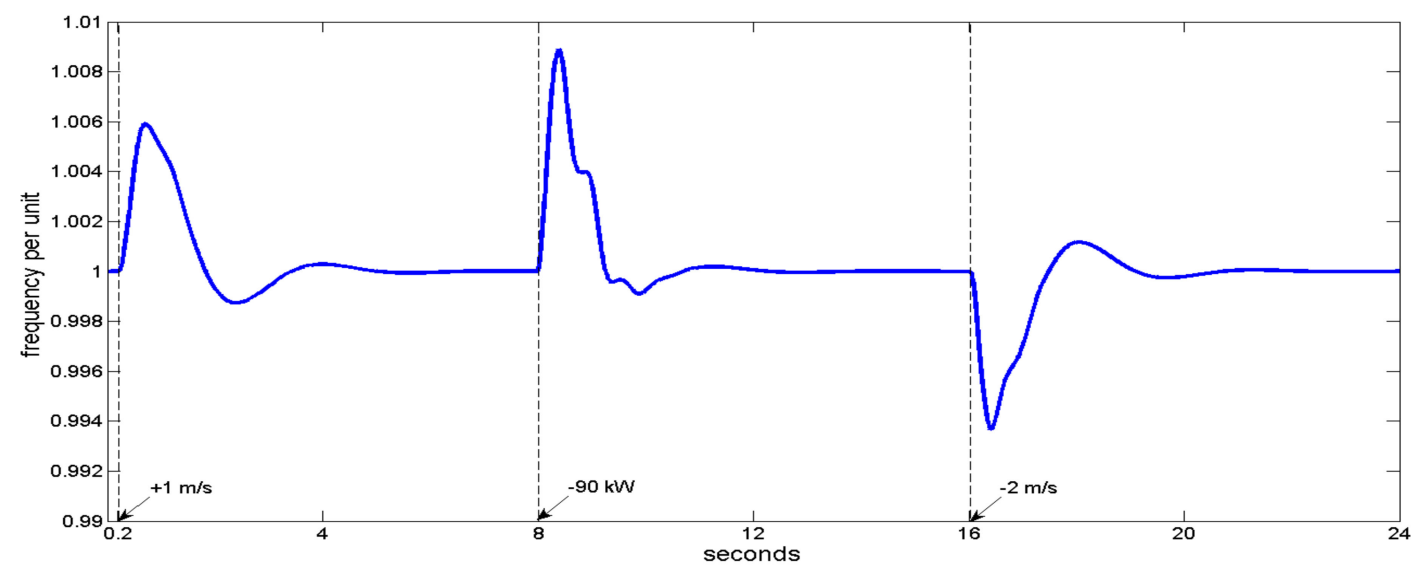

Figure 7. WDIM frequency pu. 


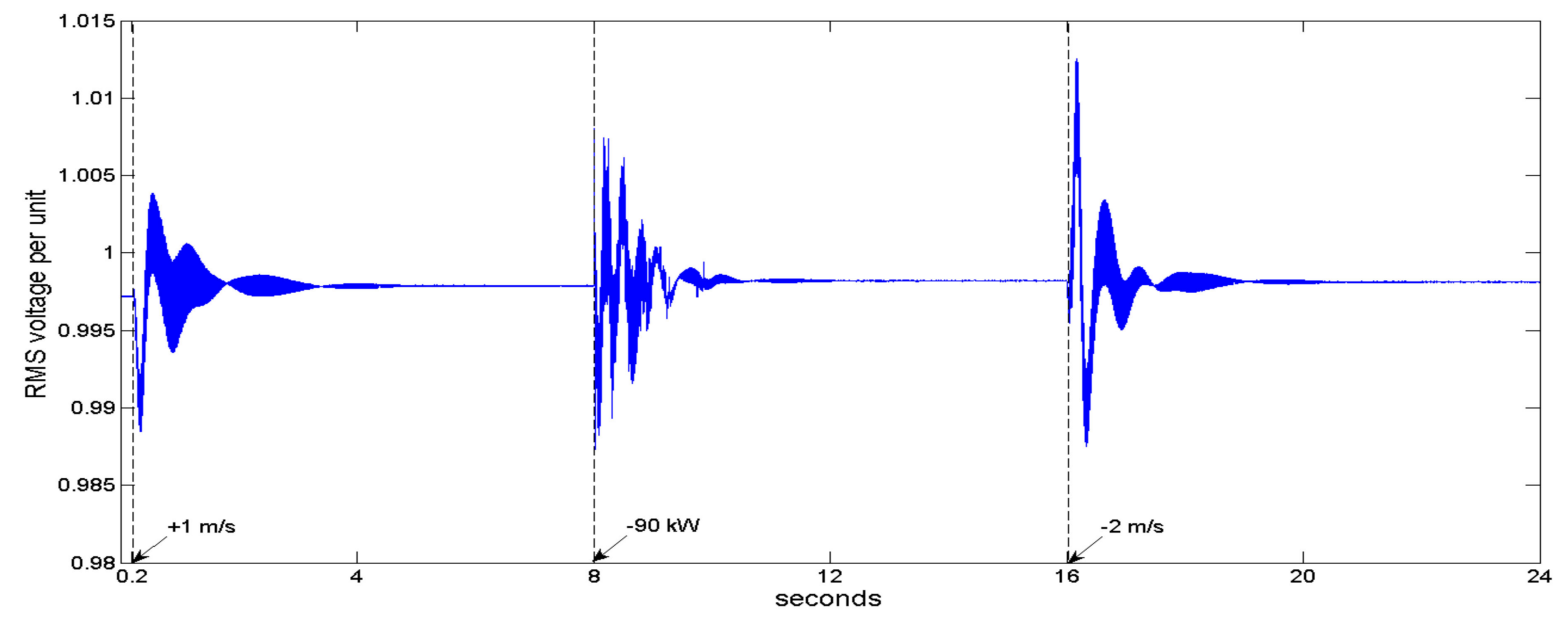

Figure 8. WDIM voltage (RMS) pu.

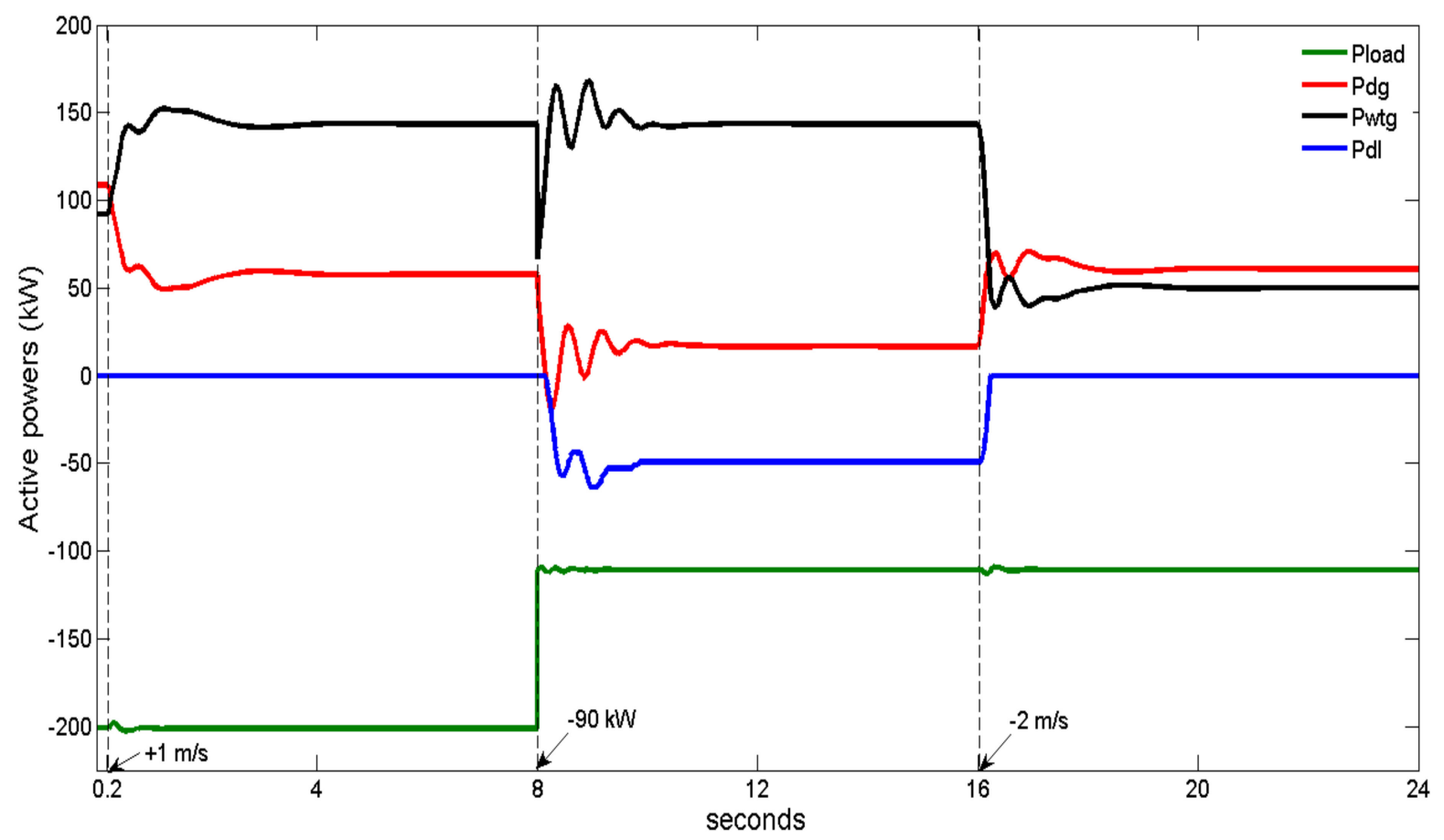

Figure 9. Generated (+)/consumed (-) active powers in the WDIM components.

The wind speed increases at $t=0.2 \mathrm{~s}$ by $1 \mathrm{~m} / \mathrm{s}$ to a $9 \mathrm{~m} / \mathrm{s}$ final value. Figure 9 shows an increasing WTG power from the initial $92 \mathrm{~kW}$ to the final $143 \mathrm{KW}$. The DG consequently decreases its power, and the final DG-produced power is $57 \mathrm{~kW}$. The fpu graph first increases due to the active power excess (1.0059 maximum) and then undershoots (0.9987 minimum), and the voltage pu minimum and maximum are 0.9885 and 1.0039 , respectively. The DL is not actuated, and its power is 0 as the DG power remains above $12 \mathrm{~kW}$ during the whole $0.2-8 \mathrm{~s}$ time interval.

By opening the circuit breaker of Figure 6 at $t=8 \mathrm{~s}$, the $90 \mathrm{~kW}$ extra load is disconnected, so the consumer load changes to $110 \mathrm{~kW}$, a value below the $143 \mathrm{~kW}$ WTG power. The DG reacts by reducing its power, and when its value is below $12 \mathrm{~kW}$, the DL integral control starts ordering power consumption to the DL to prevent the DG reverse power. While the DL increases its consumed power to fit the DG active power in the 12-18 kW interval, both the DG and WTG active powers present oscillations. The initial excess of active power makes the fpu increase (1.0089 maximum), and then the fpu undershoots (0.9991 minimum). The voltage pu minimum and maximum are 0.9873 and 1.0081, respectively. The wind 
speed remains constant, so the final WTG power is the initial one at $t=8 \mathrm{~s}$. In steady state, the DG produces $16.5 \mathrm{~kW}$ (a value in the 12-18 range), and the DL consumes $49.5 \mathrm{~kW}$ (the DG minimum load plus the WTG active power excess).

At $t=16 \mathrm{~s}$, a negative wind speed step of $-2 \mathrm{~m} / \mathrm{s}$ is applied. The WTG power decreases to $50 \mathrm{KW}$ final value. The DG reacts and increases its power over $18 \mathrm{~kW}$ so that the DL decreases its consumed power commanded by its integral control. The DL power reaches and stays at zero as the DG power remains greater than $18 \mathrm{KW}$. The initial lack of active power makes the fpu decrease (0.9937 minimum), and then it overshoots (1.0012 maximum). The voltage pu minimum and maximum are 0.9875 and 1.0126, respectively. The final active powers for the DG, WTG and DL are 60, 50 and $0 \mathrm{~kW}$, respectively.

\section{Conclusions}

After a description of the different components that form a WDIM and the different modes of WDIM operation and a brief introduction about WDIM dynamic and logistic simulation, papers about the dynamic simulation of WDIMs have been reviewed. The review has been classified according to several WDIM issues: the WTG types that WDIMs include, the use of different ESS technologies in WDIMs, the simulation of WDIM operation modes (or simulation of transitions between modes) and the WDIM power quality and stability studies. Additionally, a brief review of WDIM-related isolated microgrids has been presented. Finally, as an example of WDIM dynamic simulation, a no-storage WDIM has been first modeled and then simulated using Matlab-Simulink SW. In the presented simulations, the WDIM works in WD mode, and it is shown how a DL increases the WDIM stability and reliability by consuming the WTG power excess.

Funding: This research received no external funding.

Institutional Review Board Statement: Not applicable.

Informed Consent Statement: Not applicable.

Data Availability Statement: Not applicable.

Conflicts of Interest: The author declares no conflict of interest.

$\begin{array}{ll}\text { Abbreviations } & \\ \text { DE } & \text { Diesel engine } \\ \text { DFIG } & \text { Double-feed induction generator } \\ \text { DG } & \text { Diesel generator } \\ \text { DL } & \text { Dump load } \\ \text { ESS } & \text { Energy storage system } \\ \text { BESS } & \text { Battery ESS } \\ \text { FESS } & \text { Flywheel ESS } \\ \text { CESS } & \text { Supercapacitor ESS } \\ \text { PMSG } & \text { Permanent magnet synchronous generator } \\ \text { SCIG } & \text { Squirrel-cage induction generator } \\ \text { SM } & \text { Synchronous machine } \\ \text { WDIM } & \text { Wind diesel isolated microgrid } \\ \text { WDIM operation modes } & \text { Diesel only (DO), wind-diesel (WD), wind only (WO) } \\ \text { WT } & \text { Wind turbine } \\ \text { WTG } & \text { Wind turbine generator }\end{array}$

\section{References}

1. Vazquez, S.; Lukic, S.M.; Galvan, E.; Franquelo, L.G.; Carrasco, J.M. Energy Storage Systems for Transport and Grid Applications. IEEE Trans. Ind. Electron. 2010, 57, 3881-3895. [CrossRef]

2. Hunter, R.; Elliot, G. (Eds.) Wind-Diesel Systems: A Guide to the Technology and Its Implementations; Cambridge University Press: Cambridge, UK, 1994. 
3. Sebastián, R.; García-Loro, F. Review on Wind Diesel Systems Dynamic Simulation. In Proceedings of the IECON 2019-45th Annual Conference of the IEEE Industrial Electronics Society, Lisbon, Portugal, 14-17 October; IEEE: New York, NY, USA, 2019; pp. 2489-2494.

4. Sebastián, R. Reverse power management in a wind diesel system with a battery energy storage. Int. J. Electr. Power Energy Syst. 2013, 44, 160-167. [CrossRef]

5. Psarros, G.N.; Karamanou, E.G.; Papathanassiou, S.A. Feasibility Analysis of Centralized Storage Facilities in Isolated Grids. IEEE Trans. Sustain. Energy 2018, 9, 1822-1832. [CrossRef]

6. Fernandez, R.S. Simulation of the transition from Wind only mode to Wind Diesel mode in a no-storage Wind Diesel System. IEEE Latin Am. Trans. 2009, 7, 539-544. [CrossRef]

7. Sebastián, R. Smooth transition from wind only to wind diesel mode in an autonomous wind diesel system with a battery-based energy storage system. Renew. Energy 2008, 33, 454-466. [CrossRef]

8. Sebastián, R. Battery energy storage for increasing stability and reliability of an isolated Wind Diesel power system. IET Renew. Power Gener. 2017, 11, 296-303. [CrossRef]

9. Drouilhet, S. Power Flow Management in a High Penetration Wind-Diesel Hybrid Power System with a Short-Term Energy Storage; Wind Power 99: Vermont, VT, USA, 1999.

10. Manwell, J.F.; Rogers, A.; Hayman, G.; Avelar, C.T.; McGowan, J.G.; Abdulwahid, U.; Wu, K. Hybrid2—A Hybrid System Simulation Model Theory Manual; Renewable Energy Research Laboratory, Department of Mechanical Engineering, University of Massachusetts: Amherst, MA, USA, 2006.

11. Lambert, T.; Gilman, P.; Lilienthal, P. Micropower System Modeling with HOMER, Integration of Alternative Sources of Energy; Farret, F.A., Simões, M.G., Eds.; John Wiley \& Sons: Hoboken, NJ, USA, 2005; ISBN 0471712329.

12. Saha, T.K.; Kastha, D. Design Optimization and Dynamic Performance Analysis of a Stand-Alone Hybrid Wind-Diesel Electrical Power Generation System. IEEE Trans. Energy Convers. 2010, 25, 1209-1217. [CrossRef]

13. PSCAD. Manitoba Hydro International Ltd. Available online: https://www.pscad.com/ (accessed on 26 November 2020).

14. Simscape Electrical ${ }^{\mathrm{TM}}$ Libraries. Available online: https://es.mathworks.com/products/simscape-electrical.html (accessed on 26 November 2020).

15. Bialasiewicz, J.T.; Muljadi, E. Analysis of Renewable-Energy Systems Using RPM-SIM Simulator. IEEE Trans. Ind. Electron. 2006, 53. [CrossRef]

16. Krause, P.C.; Wasynczuk, O.; Sudhoff, S.D. Analysis of Electric Machinery and Drive Systems, 2nd ed.; Wiley-IEEE Press: Piscataway, NJ, USA, 2002.

17. Li, H.; Chen, Z. Overview of different wind generator systems and their comparisons. IET Renew. Power Gener. 2008, 2, 123-138. [CrossRef]

18. Hansen, A.; Jauch, C.; Sørensen, P.; Iov, F.; Blaabjerg, F. Dynamic Wind Turbine Models in Power System Simulation Tool DIgSILENT; Report Risø-R-1400(EN); Risø National Laboratory: Roskilde, Denmark, 2003. Available online: http://www.risoe.dk/rispubl/ VEA/veapdf/ris-r-1400.pdf (accessed on 21 March 2021).

19. Sebastián, R. Application of a battery energy storage for frequency regulation and peak shaving in a wind diesel power system. IET Gener. Transm. Distrib. 2016, 10, 764-770. [CrossRef]

20. Amenedo, J.L.R.; Diaz, J.C.B.; Gomez, S.A. Sistemas Eólicos de Producción de Energía Eléctrica; Rueda: Madrid, Spain, 2003; ISBN 9788472071391.

21. Margaris, I.D.; Papathanassiou, S.A.; Hatziargyriou, N.D.; Hansen, A.D.; Sorensen, P. Frequency Control in Autonomous Power Systems With High Wind Power Penetration. IEEE Trans. Sustain. Energy 2012, 3, 189-199. [CrossRef]

22. Papathanassiou, S.A.; Papadopoulos, M.P. Dynamic characteristics of autonomous wind-diesel systems. Renew. Energy 2001, 23, 293-311. [CrossRef]

23. Sedaghat, B.; Jalilvand, A.; Noroozian, R. Design of a multilevel control strategyfor integration of stand-alone wind/diesel system. Int. J. Electr. Power Energy Syst. 2012, 35, 123-137. [CrossRef]

24. Carrillo, C.; Feijóo, A.; Cidrás, J. Comparative study of flywheel systems in an isolated wind plant. Renew. Energy 2008. [CrossRef]

25. Iglesias, I.J.; Garcia-Tabares, L.; Agudo, A.; Cruz, I.; Arribas, L. Design and simulation of a stand-alone wind-diesel generator with a flywheel energy storage system to supply the required active and reactive power. In Proceedings of the 2000 IEEE 31st Annual Power Electronics Specialists Conference, Conference Proceedings (Cat. No.00CH37018), Galway, Ireland, 18-23 June 2000; Volume 3, pp. 1381-1386.

26. Esmaeilian, H.R.; Fadaeinedjad, R. A Remedy for Mitigating Voltage Fluctuations in Small Remote Wind-Diesel Systems Using Network Theory Concepts. IEEE Trans. Smart Grid 2018, 9, 4162-4171. [CrossRef]

27. Muljadi, E.; McKenna, H.E. Power quality issues in a hybrid power system. IEEE Trans. Ind. Appl. 2002, 38, 803-809. [CrossRef]

28. Gagnon, R.; Saulnier, B.; Sybille, G.; Giroux, P. Modelling of a Generic High-Penetration No-Storage Wind-Diesel System Using Matlab /Power System Blockset. In Proceedings of the 2002 Global Windpower Conference, Paris, France, 2-5 April 2002.

29. Sebastián, R.; Quesada, J. Distributed control system for frequency control in a isolated wind system. Renew. Energy 2006, 31, 285-305. [CrossRef]

30. Peña, R.; Cárdenas, R.; Proboste, J.; Clare, J.; Asher, G. Wind-Diesel Generation Using Doubly Fed Induction Machines. IEEE Trans. Energy Convers. 2008, 23, 202-214. [CrossRef] 
31. Tiwari, S.K.; Singh, B.; Goel, P.K. Control of wind diesel hybrid system with BESS for optimal operation. In Proceedings of the 2016 IEEE 7th Power India International Conference (PIICON), Bikaner, India, 25-27 November 2016; pp. 1-6.

32. Kayikci, M.; Milanovic, J.V. Dynamic Contribution of DFIG-Based Wind Plants to System Frequency Disturbances. IEEE Trans. Power Syst. 2009, 24, 859-867. [CrossRef]

33. Kamal, E.; Koutb, M.; Sobaih, A.A.; Abozalam, B. An intelligent maximum power extraction algorithm for hybrid wind-dieselstorage system. Int. J. Electr. Power Energy Syst. 2010, 32, 170-177. [CrossRef]

34. Haruni, A.M.O.; Gargoom, A.; Haque, M.E.; Negnevitsky, M. Dynamic operation and control of a hybrid wind-diesel stand alone power systems. In Proceedings of the 2010 Twenty-Fifth Annual IEEE Applied Power Electronics Conference and Exposition (APEC), Palm Springs, CA, USA, 21-25 February 2010; pp. 162-169.

35. Mendis, N.; Muttaqi, K.M.; Perera, S. Management of Battery-Supercapacitor Hybrid Energy Storage and Synchronous Condenser for Isolated Operation of PMSG Based Variable-Speed Wind Turbine Generating Systems. IEEE Trans. Smart Grid 2014, 5, 944-953. [CrossRef]

36. Lukasievicz, T.; Oliveira, R.; Torrico, C. A Control Approach and Supplementary Controllers for a Stand-Alone System with Predominance of Wind Generation. Energies 2018, 11, 411. [CrossRef]

37. Yang, T.C. On embedded energy storage for high penetration of wind power. Wind Eng. 2008, 32, 223-242. [CrossRef]

38. Beyer, H.G.; Degner, T.; Gabler, H. Operational behaviour of wind diesel systems incorporating short-term storage: An analysis via simulation calculations. Sol. Energy 1995, 54, 429-439. [CrossRef]

39. Shirazi, M.; Droulihet, S. An analysis of the performance benefits of Short-Term Energy Storage in Wind-Diesel Hybrid Power Systems. In Proceedings of the ASME Wind Energy Symposium, Reno, NV, USA, 6-9 January 1997.

40. Sebastián, R.; Peña Alzola, R. Simulation of an isolated Wind Diesel System with battery energy storage. Electr. Power Syst. Res. 2011, 81, 677-686. [CrossRef]

41. Rezkallah, M.; Chandra, A. Wind diesel battery hybrid system with power quality improvement for remote communities. In Proceedings of the IEEE Industry Applications Society Annual Meeting (IAS), Orlando, FL, USA, 9-13 October 2011; pp. 1-6.

42. Denmark Adrees, A.; Andami, H.; Milanović, J.V. Comparison of dynamic models of battery energy storage for frequency regulation in power system. In Proceedings of the 2016 18th Mediterranean Electrotechnical Conference (MELECON), Lemesos, Cyprus, 18-20 April 2016; pp. 1-6. [CrossRef]

43. Sebastián, R.; Peña-Alzola, R. Study and simulation of a battery based energy storage system for wind diesel hybrid systems. In Proceedings of the 2012 IEEE International Energy Conference and Exhibition (ENERGYCON), Florence, Italy, 9-12 September; 2012; pp. 563-568.

44. Tremblay, O.; Dessaint, L.-A.; Dekkiche, A.-I. A generic battery model for the dynamic simulation of hybrid electric vehicles. In Proceedings of the Vehicle Power and Propulsion Conference, 2007, VPPC 2007, Arlington, TX, USA, 9-12 September; 2007; pp. 284-289.

45. Li, X.; Hui, D.; Lai, X. Battery energy storage station (BESS)-based smoothing control of photovoltaic (PV) and wind power generation fluctuations. IEEE Trans. Sustain. Energy 2013, 4, 464-473. [CrossRef]

46. Coleman, M.; Zhu, C.B.; Lee, C.K.; Hurley, W.G. A combined SOC estimation method under varied ambient temperature for a lead-acid battery. In Proceedings of the Twentieth Annual IEEE Applied Power Electronics Conference and Exposition, 2005, APEC 2005, Austin, TX, USA, 6-10 March; 2005; Volume 2, pp. 991-997.

47. Sidorov, D.; Muftahov, I.; Tomin, N.; Karamov, D.; Panasetsky, D.; Dreglea, A.; Foley, A. A Dynamic Analysis of Energy Storage With Renewable and Diesel Generation Using Volterra Equations. IEEE Trans. Ind. Inform. 2020, 16, 3451-3459. [CrossRef]

48. Bindner, H.; Cronin, T.; Lundsager, P.; Manwell, J.F.; Abdulwahid, U.; Baring-Gould, I. Lifetime Modelling of Lead Acid Batteries; Risø National Laboratory Report; Risø National Laboratory: Roskilde, Denmark, 2005; 81p, ISBN 87-550-3441-1.

49. Sebastian, R. Modelling and simulation of a high penetration wind diesel system with battery energy storage. Int. J. Electr. Power Energy Syst. 2011, 33, 767-774. [CrossRef]

50. Chau, K.T. 21-Pure electric vehicles. In Alternative Fuels and Advanced Vehicle Technologies for Improved Environmental Performance; Richard, F., Ed.; Woodhead Publishing: Sawston, UK; pp. 655-684, ISBN 9780857095220.

51. Tarkeshwar, M.; Mukherjee, V. Quasi-oppositional harmony search algorithm and fuzzy logic controller for load frequency stabilisation of an isolated hybrid power system. IET Gener. Transm. Distrib. 2015, 9, 427-444. [CrossRef]

52. Perelmuter, V.M. Advanced Simulation of Alternative Energy Simulation with Simulink ${ }^{\circledR}$ and SimPowerSystems ${ }^{\mathrm{TM}}$; CRC Press: Boca Raton, FL, USA, 2020; ISBN 9780367339579.

53. Sebastián, R.; Peña-Alzola, R. Control and simulation of a flywheel energy storage for a wind diesel power system. Int. J. Electr. Power Energy Syst. 2015, 64, 1049-1056. [CrossRef]

54. Sebastián, R.; Alzola, R.P. Flywheel energy storage systems: Review and simulation for an isolated wind power system. Renew. Sustain. Energy Rev. 2012, 16, 6803-6813. [CrossRef]

55. Zargar, M.Y.; Mufti MU, D.; Lone, S.A. Adaptive predictive control of a small capacity SMES unit for improved frequency control of a wind-diesel power system. IET Renew. Power Gener. 2017, 11, 1832-1840. [CrossRef]

56. Ali, M.H.; Wu, B.; Dougal, R.A. An Overview of SMES Applications in Power and Energy Systems. IEEE Trans. Sustain. Energy 2010, 1, 38-47. [CrossRef]

57. Mipoung, O.D.; Lopes, L.A.C.; Pillay, P. Frequency Support From a Fixed-Pitch Type-2 Wind Turbine in a Diesel Hybrid Mini-Grid. IEEE Trans. Sustain. Energy 2014, 5, 110-118. [CrossRef] 
58. Mahela, O.P.; Shaik, A.G. Comprehensive overview of grid interfaced wind energy generation systems. Renew. Sustain. Energy Rev. 2016, 57, 260-281. [CrossRef]

59. Tang, X.; Deng, W.; Qi, Z. Investigation of the Dynamic Stability of Microgrid. IEEE Trans. Power Syst. 2014, $29,698-706$. [CrossRef]

60. Kassem, A.M.; Abdelaziz, A.Y. Optimal control of an autonomous variable speed wind generation system based on a bacterial foraging optimization technique. Electr. Power Compon. Syst. 2015, 43, 1006-1017. [CrossRef]

61. Sebastián, R.; Quesada, J. Coordinated control of a battery energy storage and a Dump load in an autonomous Wind Power System. In Proceedings of the 2020 IEEE International Conference on Environment and Electrical Engineering and 2020 IEEE Industrial and Commercial Power Systems Europe (EEEIC/I\&CPS Europe), Madrid, Spain, 9-12 June 2020; pp. 1-6. [CrossRef]

62. Muljadi, E.; Bialasiewicz, J.T. Hybrid power system with a controlled energy storage. In Proceedings of the Industrial Electronics Conference, IECON'03, Roanoke, VA, USA, 2-6 November 2003; Volume 2, pp. 1296-1301.

63. Sebastián, R.; Alzola, R.P. Effective active power control of a high penetration wind diesel system with a Ni-Cd battery energy storage. Renew. Energy 2010, 35, 952-965. [CrossRef]

64. Sebastian, R.; Castro, M.; Sancristobal, E.; Yeves, F.; Peire, J.; Quesada, J. Approaching hybrid wind-diesel systems and controller area network. In Proceedings of the IEEE 2002 28th Annual Conference of the Industrial Electronics Society, IECON 02, Sevilla, Spain, 5-8 November 2002; Volume 3, pp. 2300-2305.

65. Kassem, A.M.; Abdelaziz, A.Y. Reactive power control for voltage stability of standalone hybrid wind-diesel power system based on functional model predictive control. IET Renew. Power Gener. 2014, 8, 887-899. [CrossRef]

66. Janssen, N.T.; Wies, R.W.; Peterson, R.A. Frequency regulation by distributed secondary loads on islanded wind-powered microgrids. IEEE Trans. Sustain. Energy 2016, 7, 1028-1035. [CrossRef]

67. Zhang, Y.; Melin, A.M.; Djouadi, S.M.; Olama, M.M.; Tomsovic, K. Provision for guaranteed inertial response in diesel-wind systems via model reference control. IEEE Trans. Power Syst. 2018, 33, 6557-6568. [CrossRef]

68. Kouba NE, Y.; Menaa, M.; Hasni, M.; Boudour, M. A novel optimal frequency control strategy for an isolated wind-diesel hybrid system with energy storage devices. Wind Eng. 2016, 40, 497-517. [CrossRef]

69. Sebastián, R.; Peña-Alzola, R. Flywheel Energy Storage and Dump Load to Control the Active Power Excess in a Wind Diesel Power System. Energies 2020, 13, 2029. [CrossRef]

70. Lasseter, R. Microgrids. In Proceedings of the IEEE PES Winter Meeting, New York, NY, USA, 27-31 January 2002; Volume 1, pp. 305-308.

71. Basak, P.; Chowdhury, S.; Dey, S.H.N.; Chowdhury, S.P. A literature review on integration of distributed energy resources in the perspective of control, protection and stability of microgrid. Renew. Sustain. Energy Rev. 2012, 16, 5545-5556. [CrossRef]

72. Piagi, P.; Lasseter, R.H. Autonomous Control of Microgrids. In Proceedings of the IEEE PES Meeting, Montreal, QC, Canada, 19 June 2006.

73. Serban, I.; Marinescu, C. Control Strategy of Three-Phase Battery Energy Storage Systems for Frequency Support in Microgrids and with Uninterrupted Supply of Local Loads. IEEE Trans. Power Electron. 2014, 29, 5010-5020. [CrossRef]

74. Bø, T.I.; Johansen, T.A. Battery Power Smoothing Control in a Marine Electric Power Plant Using Nonlinear Model Predictive Control. IEEE Trans. Control Syst. Technol. 2017, 25, 1449-1456. [CrossRef]

75. Krishnamurthy, S.; Jahns, T.M.; Lasseter, R.H. The operation of diesel gensets in a CERTS microgrid. In Proceedings of the 2008 IEEE Power and Energy Society General Meeting-Conversion and Delivery of Electrical Energy in the 21st Century, Pittsburgh, PA, USA, 20-24 July 2008; pp. 1-8.

76. Tan, Y.; Meegahapola, L.; Muttaqi, K.M. A review of technical challenges in planning and operation of remote area power supply systems. Renew. Sustain. Energy Rev. 2014, 38, 876-889. [CrossRef]

77. Krata, J.; Saha, T.K. Real-Time Coordinated Voltage Support with Battery Energy Storage in a Distribution Grid Equipped with Medium-Scale PV Generation. IEEE Trans. Smart Grid 2018, 10, 3486-3497. [CrossRef]

78. Asghar, F.; Talha, M.; Kim, S.H. Fuzzy logic based intelligent frequency and voltage stability control system for standalone microgrid. Int. Trans. Electr. Energy Syst. 2018, 28, e2510. [CrossRef]

79. Madiba, T.; Bansal, R.C. Optimal Load-Shedding Control of a Microgrid Power System. Electr. Power Compon. Syst. 2018, 46, 768-787. [CrossRef]

80. Vidyanandan, K.V.; Nilanjan, S. Frequency regulation in a wind-diesel powered microgrid using flywheels and fuel cells. IET Gener. Transm. Distrib. 2016, 10, 780-788. [CrossRef]

81. Lee, D.; Wang, L. Small-Signal Stability Analysis of an Autonomous Hybrid Renewable Energy Power Generation/Energy Storage System Part I: Time-Domain Simulations. IEEE Trans. Energy Convers. 2008, 23, 311-320. [CrossRef]

82. Taghizadeh, M.; Mardaneh, M.; Sadeghi, M.S. Frequency control of a new topology in proton exchange membrane fuel cell/wind turbine/photovoltaic/ultra-capacitor/battery energy storage system based isolated networks by a novel intelligent controller. J. Renew. Sustain. Energy 2014, 6, 053121. [CrossRef]

83. Aghamohammadi, M.R.; Abdolahinia, H. A new approach for optimal sizing of battery energy storage system for primary frequency control of islanded Microgrid. Int. J. Electr. Power Energy Syst. 2014, 54, 325-333. [CrossRef]

84. Paish, O. Small hydro power: Technology and current status. Renew. Sustain. Energy Rev. 2002, 6, 537-556. [CrossRef]

85. Sebastián, R.; Nevado, A. Study and Simulation of a Wind Hydro Isolated Microgrid. Energies 2020, 13, 5937. [CrossRef] 
86. Platero, C.A.; Nicolet, C.; Sánchez, J.A.; Kawkabani, B. Increasing wind power penetration in autonomous power systems through no-flow operation of Pelton turbines. Renew. Energy 2014, 68, 515-523. [CrossRef]

87. Sarasúa, J.; Martínez-Lucas, G.; Platero, C.; Sánchez-Fernández, J. Dual Frequency Regulation in Pumping Mode in a Wind-Hydro Isolated System. Energies 2018, 11, 2865. [CrossRef]

88. Sarasúa, J.I.; Martínez-Lucas, G.; Lafoz, M. Analysis of alternative frequency control schemes for increasing renewable energy penetration in El Hierro Island power system. Int. J. Electr. Power Energy Syst. 2019, 113, 807-823. [CrossRef]

89. Rezkallah, M.; Chandra, A.; Singh, B.; Singh, S. Microgrid: Configurations, Control and Applications. IEEE Trans. Smart Grid 2019, 10, 1290-1302. [CrossRef]

90. Yeager, K.E.; Willis, J.R. Modelling of emergency diesel generators in an 800 Megawatt nuclear power plant. IEEE Trans. Energy Convers. 1994, 8, 433-441. [CrossRef] 